\title{
LANDFILL PLASTIC TO LIQUID OIL
}

\author{
Hella Riisalu ${ }^{1}$ \\ Dmitri Suštšik ${ }^{1}$ \\ Rein Muoni ${ }^{1}$ \\ Mait Kriipsalu ${ }^{2}$ \\ ${ }^{1}$ Tallinn University of Technology, Estonia \\ ${ }^{2}$ Estonian University of Life Sciences, Estonia \\ *Corresponding author: hella.riisalu@gmail.com
}

\begin{abstract}
A full-scale Landfill Mining (LFM) project was made in 2012-2013 in Estonia at Kudjape Landfill. As a result of mining, mixed plastic waste was separated from excavated material. After sieving and shredding the received plastic fraction was washed and dried for further research.

The waste plastic may be incinerated for energy and heat recovery or used as solid recovered fuel in cement industry. However, more favoured could be reprocessing this material to liquid fuel. A series of experiments were made to study pyrolysis of landfill plastic after being buried for up to ten years. Mixed plastic was treated thermally by semi-coking process as used by thermal treatment of oil shale in Estonia. The preliminary studies have shown, that oil, gas and solid carbon-rich residue may be received. All of these products show value as energy source.

In this project, interdisciplinary research was done by Estonian University of Life Sciences (responsible for mining, sorting, pre-treatment and washing of landfill plastic), and Tallinn University of Technology (responsible for semi-coking of plastic waste and analyses of endproducts). Results, conclusions, and proposals are presented in the article.
\end{abstract}

\section{KEYWORDS}

Mixed landfill plastic, Pyrolysis, Semi-coking, Oil, Gas, Carbon-rich residue, Energy

\section{INTRODUCTION}

A full-scale Landfill Mining (LFM) project was made in 2012-2013 in Estonia at Kudjape Landfill. As a result of mining, mixed plastic waste (MPW) was separated from excavated material. Even when attempts are made to separate different plastic types at the landfill for material recycling, quality is likely to be comparatively poor and the processing cost high. Fresh mixed plastic from mechanical separation plants are typically sent for use as Refuse Derived Fuel (RDF) or Solid Recovered Fuel (SRF). The most practical way to utilise waste plastic is likely to be incinerated for energy and heat recovery or used as SRF in cement industry [1]. However, more favoured could be reprocessing this material into liquid fuel [2]. 


\section{Linnaeus ECO-TECH '14}

Kalmar, Sweden, November 24-26, 2014

After sieving and shredding the received landfill plastic (LP) fraction was washed and dried for this research.

Two main types of conversion of MPW to liquid fuel are gasification and pyrolysis. Both technologies have been successfully used in processing biomass and homogeneous industrial waste products [2]. Gasification and pyrolysis are thermal conversion technologies that happen under different amount of air present in the system.

Gasification occurs in the presence of limited amounts of air (or oxygen) that allows partial combustion of the material. Gasification leads to combustible synthesis gas (syngas) as a final product. Syngas is a valuable commercial product used as an intermediate to create synthesis natural gas, methane, methanol, dimethyl ether and other chemicals. It can also be used directly to produce energy as a surrogate for natural gas [3]. The disadvantage is that hightemperature gasification is a very energy-consuming process and has not become a dominating industrial application in waste management so far.

Pyrolysis occurs in the complete absence of air (or oxygen). Pyrolysis leads to synthetic liquid fuel similar to crude oil and by-products as solid carbon and combustible synthetic gases. Liquid product can be mixed with crude oil and further refined to gasoline and other petroleum products [3]. Pyrolysis is achieved at relatively low temperatures compared to gasification, and it has been industrially applied on treatment of different materials. The conditions of pyrolysis depend on primary materials. Pyrolysis of landfill plastics, however, is less studied.

In Estonia, pyrolysis processes called semi-coking have been commercially utilised during several decades. It seems reasonable to use this experience for studying pyrolysis of mixed LP. A standard way of preliminary study of oil shale semi-coking process was used also by low temperature treatment of LP.

\section{METHODS AND RESULTS}

Samples of preliminary shredded, washed and dried LP fraction were produced by Estonian University of Life Sciences. The pyrolysis testing was fulfilled by laboratory of fuels of Oil Shale Competence Centre of Virumaa College of Tallinn University of Technology. The standard procedures of oil shale studies were used, including Fisher assay equipment. The standard procedure by ISO 647 was taken as basis [4]. The pyrolysis was carried out with LP samples of $100 \mathrm{~g}$ at temperatures-time regime as following:

1. $520{ }^{\circ} \mathrm{C}-80 \mathrm{~min}$;

2. $500{ }^{\circ} \mathrm{C}-90 \mathrm{~min}$;

3. $500{ }^{\circ} \mathrm{C}-130 \mathrm{~min}$.

Because the amount of oil from Fischer assay is too small to carry out the analytical oil tests correctly, the pyrolysis of $2.5 \mathrm{~kg}$ LP was carried out in bench-scaled retort, provided with equipment to collect products of thermal treatment.

\section{RESULTS AND DISCUSSION}

Approximately 40-50 \% of LP may be converted to crude oil. The pyrolysis was carried out in the studied conditions with each regime as described in Table 1. Highest yield of oil was obtained at $520{ }^{\circ} \mathrm{C}, 80 \mathrm{~min}$. Lower temperatures and longer retention time provides higher yield of solid residues. Water content was similar at all experiments; off-gasses and losses were at a range of 15.29 to $17.74 \%$. 


\section{Linnaeus ECO-TECH '14}

Kalmar, Sweden, November 24-26, 2014

Table 1 Yields of pyrolysis products \%

\begin{tabular}{lccc}
\hline & \multicolumn{3}{c}{ Temperature-time regime } \\
& $\mathrm{I}-520{ }^{\circ} \mathrm{C}, 80 \mathrm{~min}$ & $\mathrm{II}-500{ }^{\circ} \mathrm{C}, 90 \mathrm{~min}$ & $\mathrm{III}-500{ }^{\circ} \mathrm{C}, 130 \mathrm{~min}$ \\
\hline Oil & 48.10 & 45.43 & 41.91 \\
Solid residue & 32.20 & 35.76 & 36.97 \\
Water & 3.20 & 3.53 & 3.39 \\
Gas + losses & 16.50 & 15.29 & 17.74 \\
\hline
\end{tabular}

In bench-scaled retort, the temperature characteristics are described on Figure 1 and results of oil and solid residue in table 2. Waste heats slowly in a retort, and heat penetrates slowly into waste plastic. Appearance of oil is heavy brown liquid. Its density is $855.8 \mathrm{~kg} / \mathrm{m}^{3}$, sulphur content is $0.16 \%$, and calorific value is $41.9 \mathrm{MJ} / \mathrm{kg}$.



Time, $\min$

Figure 1. Changes of temperatures in bench-scale test

Table 2. Characteristics of materials in bench-scale oil

\begin{tabular}{lccc}
\hline Characteristics & Standard & Unit & Results \\
\hline \multicolumn{1}{c}{ Oil } & & & \\
Appearance & & & Heavy brown liquid \\
Density by $15{ }^{\circ} \mathrm{C}$ & EVS-EN ISO 3675 & $\mathrm{kg} / \mathrm{m}^{3}$ & 855.8 \\
Kinematic viscosity by $50{ }^{\circ} \mathrm{C}$ & EVS-EN ISO 3104 & $\mathrm{mm}^{2} / \mathrm{s}$ & 7.9 \\
Sulphur content & EVS-EN ISO 20846 & mass \% & 0.16 \\
Heat of combustion & ASTM D 240 & $\mathrm{MJ} / \mathrm{kg}$ & 41.9 \\
\multicolumn{1}{c}{ Solid residues } & & & Black solid material \\
Appearance & & & \\
Elemental analysis (C,H, N) & ASTM D 5373 & & 18.0 \\
$\mathrm{C}^{\mathrm{d}}$ & ASTM D 5373 & $\%$, mass & 0.7 \\
$\mathrm{H}^{\mathrm{d}}$ & ASTM D 5373 & $\%$, mass & 0.5 \\
$\mathrm{~N}^{\mathrm{d}}$ & ASTM D 240 & $\%$, mass & \\
\hline
\end{tabular}




\section{Linnaeus ECO-TECH '14}

Kalmar, Sweden, November 24-26, 2014

The possibility of LP pyrolysis by oil shale treatment conditions was successfully proved. The preliminary studies of treatment products show high yield of crude oil with low content of sulphur, which is very important for engine fuels. After further treatment (refining) this oil, the high quality diesel and heavy fuels may be produced. The high viscosity is characteristic feature also for shale oil with high content of long-chain hydrocarbons from some deposits. The solid residue and gas may be used as fuels independently or as heat source by pyrolysis. One more possibility is co-pyrolysis with oil shale [5] or other organic materials (wood waste as example) which should be also studied.

\section{CONCLUSIONS}

The landfill plastics are valuable source of fuels. Low-temperature pyrolysis or semi-coking similarly oil shale is the promising process for thermal treatment of landfill plastics. All products of pyrolysis may be used as fuels. However, further studies are needed, and upscaling of the process is necessary.

\section{REFERENCES}

[1] Zhou, C., Fang, W., Xu, W., Cao, A., Wang, R. 2014. Characteristics and the recovery potential of plastic wastes obtained from landfill mining. Journal of Cleaner Production, Vol 80, 80-86

[2] Dezhen Chen, D., Yin, L., Wang, H., He, P. 2014. Pyrolysis technologies for municipal solid waste: A review. Waste Management, in press

[3] Gasification of Non-Recycled Plastics from Municipal Solid Waste in the United States. 2013. Report for the American Chemistry Council. September 2013, 14-15.

[4] ISO 647:1974. Brown coals and lignites - Determination of the yields of tar, water, gas and coke residue by low temperature distillation (reviewed in 2009).

[5] Tiikma, L., Luik, H., Prjadka, N. 2004. Co-pyrolysis of Estonian shales with low-density polyethylene. Oil Shale, Vol. 21.1, 75-85 